\title{
PERKEMBANGAN EMOSI MANUSIA
}

Oleh : Rini Susanti

\section{Abstrak}

Emosi mempunyai peranan penting dalam kehidupan manusia karena mempengaruhi penyesuaian pribadi dan sosial. Pertumbuhannya bervariasi pada semua orang. Emosi dikendalikan oleh proses kematangan dan belajar. Katarsis emosi membersihkan seseorang dari energi yang tidak tersalurkan. Dia mencegah ledakan emosi yang dapat menimbulkan penolakan sosial.

Kata-kata kunci : emosi, pematangan, belajar, katarsis.

\section{A. PENDAHULUAN}

Emosi merupakan suatu keadaan di dalam diri seseorang, yang tidak kelihatan dan sulit diukur. Emosi sulit diprogram, sifatnya unik, dan emosi merupakan milik kita sendiri. Manusia memiliki temperamen bawaan yang berbeda, sehingga rasa senang dan tidak senangpun berbeda. Berdasarkan hasil penelitian menunjukkan bahwa emosi sebagian besar merupakan fungsi biologis. Meskipun demikian, cara kita merespon terhadap emosi sangat dipengaruhi oleh faktor lingkungan.

Pada dasarnya emosi tampak sejak seseorang dilahirkan dan erat kaitannya dengan motivasi. Untuk mengkaji masalah perkembangan emosi pada anak, berikut ini akan dibahas mengenai konsep dasar, proses dan pola perkembangan bagi pendidikan.

*) Rini Susanti, M.Pd. adalah Staf Sub Bidang Evaluasi Sistem Pustekkom Depdiknas 


\section{B. KONSEP DASAR EMOSI}

Emosi adalah kondisi tergerak (a state of being moved) yang memiliki komponen penghayatan perasaan subyektif, impuls untuk berbuat dan kesadaran (awareness) tentang perasaan yang dihayatinya (Semiawan, 1997; 153). Sedangkan Feldman (1997) mendefinisikan emosi sebagai perasaan-perasaan yang dapat mempengaruhi perilaku dan pada umumnya mengandung komponen fisiologis dan kognitif. Perasaan-perasaan tersebut bisa sangat kuat sehingga kontrol rasional tidak berfungsi (Winkel, 1983; 151). Perasaan yang kuat tersebut diikuti oleh ekspresi motorik yang berhubungan dengan suatu objek atau situasi eksternal (Gunarsa, 1989;156). Sehubungan dengan hal ini, Goleman (1997) menyatakan bahwa emosi adalah perasaan dan pikiran khas, yakni suatu keadaan biologik dan psikologik.

Berdasarkan pendapat-pendapat tersebut di atas dapat disimpulkan bahwa yang dimaksud dengan emosi adalah keadaan yang kuat dan kompleks yang diikuti oleh ekspresi motorik serta mengandung unsur afeksi dan pikiran yang khas, yang mempengaruhi perilaku. Keadaan afeksi yang disadari dapat berupa kegembiraan, ketakutan, kebencian, cinta dan sebagainya.

\section{PROSES DAN POLA PERKEMBANGAN EMOSI}

Menurut Hurlock (1995), proses, pola perkembangan emosi pada anak, ciri-ciri emosi, dan pola umum emosi dapat dijelaskan sebagai berikut.

\section{Proses dan pola perkembangan emosi}

Proses perkembangan emosi berlangsung sejak bayi lahir sampai dewasa melalui pola-pola tertentu. Perkembangan emosi dipengaruhi oleh faktor bawaan dan pengaruh lingkungan, yaitu melalui proses pematangan dan proses belajar. Bayi sejak lahir, gejala pertama perilaku emosionalnya ialah keterangsangan umum terhadap stimuli-stimuli yang kuat. Reaksi yang tidak menyenangkan dapat diperoleh dengan cara 
mengubah posisi bayi secara tiba-tiba, sekonyong-konyong membuat suara keras, merintangi gerakan bayi, membiarkan popoknya basah, dan sebagainya. Hal itu akan menimbulkan tangisan. Sebaliknya, reaksi yang menyenangkan tampak jelas pada saat bayi menyusui, mengayun-ayunkan, menepuk-nepuk, memberikan kehangatan dan membopongnya dengan mesra.

Setelah berumur 1 tahun, ekspresi emosional mereka berwujud kegembiraan, ketakutan, kemarahan, dan kebahagiaan. Selanjutnya, dengan meningkatnya usia anak, reaksi emosional dapat berwujud menjerit dan menangis, mengadakan perlawanan, melemparkan benda, lari menghindar, bersembunyi, dan mengeluarkan kata-kata. Makin bertambah usia, maka reaksi yang berwujud bahasa makin meningkat, dan reaksi gerakan otot makin berkurang. Sekitar 2-4 tahun, reaksi ledakan marah mencapai puncaknya. Kemudian tampak pola emosi yang lebih matang, seperti cemberut dan sikap bengal.

Pola perkembangan emosi, bervariasi antara anak yang satu dengan yang lainnya. Anak yang sehat cenderung kurang emosional jika dibandingkan dengan anak yang kurang sehat. Anak yang pandai, bereaksi lebih emosional terhadap berbagai macam rangsangan dan lebih mampu mengendalikan ekspresi emosinya, dibandingkan dengan anak-anak yang kurang pandai.

\section{Kondisi yang mempengaruhi perkembangan emosi}

Faktor-faktor yang mempengaruhi perkembangan emosi adalah faktor kematangan dan faktor belajar. Peran faktor kematangan, meliputi perkembangan intelektual yang menghasilkan kemampuan untuk memahami makna yang sebelumnya tidak dimengerti. Perkembangan kelenjar endokrin penting untuk mematangkan perilaku emosional. Kelenjar adrenalin yang memainkan peran utama pada energi, mengecil secara tajam pada saat bayi lahir. Kemudian kembali membesar dengan 
pesat sampai anak berusia 5 tahun, dan selanjutnya pembesarannya melambat pada usia 5-11 tahun, dan kembali membesar dengan pesat sampai usia 16 tahun.

Selanjutnya, peran faktor belajar yang turut menunjang pola perkembangan emosi pada masa kanak-kanak, adalah melalui: (a) belajar dengan cara coba dan ralat, (b) belajar dengan cara meniru atau imitasi, (c) belajar dengan cara identifikasi, (d) belajar dengan cara pengkondisian, yaitu dengan asosiasi, dan (e) belajar melalui pelatihan atau belajar di bawah bimbingan dan pengawasan.

Belajar secara coba-coba dan ralat (trial dan error) terutama melibatkan aspek reaksi. Anak belajar secara coba-coba untuk mengekspresikan dalam bentuk perilaku yang memberikan pemuasan terbesar kepadanya dan menolak perilaku yang memberikan pemuasan sedikit atau sama sekali tidak memberikan pemuasan.

Belajar dengan imitasi sekaligus mempengaruhi aspek rangsangan dan aspek reaksi. Dengan cara mengamati halhal yang membangkitkan emosi pada orang lain, anak bereaksi dengan emosi dan metode ekspresi yang sama dengan orangorang yang diamati.

Belajar dengan identifikasi sama dengan belajar secara menirukan yaitu anak menirukan reaksi emosional orang lain dan tergugah oleh rangsangan yang sama dengan rangsangan yang telah membangkitkan emosi orang yang ditiru.

Belajar melalui pengkondisian berarti belajar dengan cara asosiasi. Dalam metode ini, objek dan situasi yang pada mulanya gagal memancing reaksi emosional kemudian dapat berhasil dengan cara asosiasi. 
Belajar dengan pelatihan berarti anak-anak dirangsang untuk bereaksi terhadap rangsangan yang biasanya membangkitkan emosi yang menyenangkan dan dicegah agar tidak bereaksi secara emosional terhadap rangsangan yang membangkitkan emosi yang tidak menyenangkan.

\section{Ciri-ciri khas emosi}

Karena adanya pengaruh kematangan dan belajar, maka emosi anak kecil berbeda dengan anak yang lebih dewasa. Ciri khas penampilan emosi anak adalah sebagai berikut: (a) emosi yang kuat, yaitu bereaksi dengan intensitas yang sama, baik terhadap situasi yang remeh ataupun yang serius, (b) emosi seringkali tampak, yaitu memperlihatkan emosi mereka meningkat dan menjumpai bahwa ledakan emosional seringkali melibatkan hukuman, (c) emosi bersifat sementara, yaitu peralihan yang cepat pada anak-anak kecil dari tertawa kemudian menangis, dan sebagainya. Tetapi dengan meningkatnya usia anak, emosi mereka menjadi lebih menetap, (d) reaksi mencerminkan individualitas, yaitu secara bertahap, dengan adanya pengaruh faktor belajar dan lingkungan, perilaku yang menyertai berbagai macam emosi semakin diindividualisasikan (tiap anak berbeda reaksinya), (e) emosi berubah kekuatannya, dalam arti dengan meningkatnya usia anak, pada usia tertentu emosi yang sangat kuat berkurang kekuatannya, sedangkan emosi lainnya yang tadinya lemah berubah menjadi kuat, (f) emosi dapat diketahui melalui gejala perilaku, misalnya: gelisah, menangis, melamun, kesukaran berbicara, dan bertingkah laku yang gugup seperti menggigit kuku atau mengisap jempol.

\section{Pola umum emosi}

\section{a. Rasa takut}

Pada bayi, rasa takut ini timbul karena suara yang keras, binatang, kamar yang gelap, tempat yang tinggi, berada sendirian, rasa sakit, dan karena objek yang tidak dikenal. Pola emosi yang berhubungan dengan rasa takut, pada umumnya ialah rasa malu, rasa canggung, rasa khawatir, 
dan rasa cemas. Rasa malu, merupakan bentuk ketakutan yang ditandai oleh penarikan diri dari hubungan dengan orang lain yang tidak dikenal. Rasa canggung adalah reaksi takut terhadap manusia, bukan pada objek atau situasi. Rasa khawatir, adalah khayalan ketakutan atau gelisah tanpa alasan. Rasa cemas, ialah keadaan mental yang tidak enak berkenaan dengan sakit yang mengancam atau yang dibayangkan. Hal ini ditandai oleh kekhawatiran, ketidakenakan, dan perasaan yang tidak baik yang tidak dapat dihindari oleh seseorang.

\section{b. Rasa marah}

Rasa marah adalah ekspresi yang lebih sering diungkapkan pada masa kanak-kanak jika dibandingkan dengan rasa takut. Rangsangan yang menimbulkan kemarahan, antara lain: rintangan terhadap gerak yang diinginkan anak, rintangan terhadap aktivitas yang sudah mulai berjalan, rintangan terhadap keinginan atau niat, dan kejengkelan yang menumpuk. Reaksi terhadap kemarahan dapat diklasifikasi menjadi dua golongan, yaitu impulsif dan ditekan. Reaksi impulsif biasanya disebut agresi, yang umumnya ditujukan kepada orang lain atau objek lain. Sedangkan reaksi yang ditekan, selalu berada di bawah pengendalian atau ditekan, misalnya: dia masa bodoh, acuh tak acuh (ini disebut: impermitive, yaitu membebaskan dari hukuman).

\section{c. Rasa cemburu}

Rasa cemburu adalah reaksi normal terhadap kehilangan kasih sayang yang nyata, dibayangkan, atau ancaman kehilangan kasih sayang. Rasa cemburu timbul dari kemarahan yang menyebabkan sikap jengkel dan ditujukan kepada orang lain. Pola rasa cemburu seringkali berasal dari rasa takut yang dikombinasikan dengan rasa marah. Sumber rasa cemburu dapat dirinci sebagai berikut; (1) rasa cemburu pada kanak-kanak pada umumnya ditumbuhkan 
di rumah, artinya dari kondisi yang ada di lingkungan rumah, misalnya rasa irihati terhadap adiknya yang baru lahir, (2) situasi sosial di sekolah merupakan sumber kecemburuan bagi anak yang berusia lebih tua. Hal ini bersumber dari kecemburuan di rumah yang dibawa ke sekolah, (3) berasal dari rasa irihati, yaitu keadaan marah dan kekesalan hati yang ditujukan kepada orang yang memiliki benda yang diirikan. Ini terjadi karena ia merasa ditelantarkan dalam hal pemilikan benda-benda seperti yang dimiliki oleh anak lain.

\section{d. Dukacita}

Dukacita adalah trauma psikis, suatu kesengsaraan emosional yang disebabkan oleh hilangnya sesuatu yang dicintai. Dalam bentuk yang lebih ringan, hal ini dikenal sebagai "kesusahan" atau kesedihan. Reaksi dukacita terhadap hilangnya orang atau barang yang dicintai mungkin tampak atau ditekan, misalnya menangis (reaksi yang tampak) atau mungkin apatis, yaitu hilangnya minat terhadap hal-hal yang terjadi di dalam lingkungannya, hilangnya selera makan dan sukar tidur.

\section{e. Keingintahuan}

Anak yang penuh keingintahuan, tampak pada ciri-ciri berikut: (1) bereaksi secara positif terhadap unsur-unsur baru, aneh, tidak layak atau misterius, (2) memperlihatkan kebutuhan akan keinginan untuk lebih banyak mengetahuinya; (3) mengamati lingkungannya untuk mencari pengalaman baru, dan (4) tekun dalam memeriksa atau menyelidiki rangsangan dengan maksud untuk mengetahui seluk beluk unsur-unsur tersebut.

\section{f. Kegembiraan, keriangan, kesenangan}

Kegembiraan ialah emosi yang menyenangkan, yang juga dikenal dengan keriangan, kesenangan, atau kebahagiaan. Setiap anak berbeda-beda interaksi kegembiraannya serta cara mengekspresikannya. Ada berbagai bentuk reaksi 
kegembiraan, antara lain: diam, tenang, puas diri, sampai meluap-luap dalam kegembiraan.

\section{g. Kasih sayang}

Kasih sayang adalah reaksi emosional terhadap seseorang, binatang, atau benda. Hal ini menunjukkan perhatian yang hangat, yang bisa berwujud fisik atau kata-kata. Hal ini tumbuh melalui proses belajar. Reaksi kasih sayang, terutama diperlihatkan dengan perilaku ramah-tamah, penuh perhatian dan akrab.

\section{Emosi yang dominan}

Emosi yang dominan adalah semua emosi, salah satu atau beberapa di antaranya menimbulkan pengaruh yang terkuat terhadap perilaku seseorang. Hal ini tergantung pada pengaruh lingkungan keluarga, hubungan mereka dengan orang-orang yang berarti bagi kehidupan mereka, dan bimbingan yang mereka terima dalam mengendalikan emosi. Kondisi yang turut mempengaruhi emosi yang dominan ialah kondisi kesehatan, suasana rumah, cara mendidik anak, hubungan dengan para anggota keluarga, hubungan dengan teman sebaya, perlindungan yang berlebihan, inspirasi orang tua, dan bimbingan.

\section{Keseimbangan emosi}

Pada keseimbangan emosi, dominasi emosi yang tidak menyenangkan dapat dilawan sampai pada batas tertentu dengan emosi yang menyenangkan, dan sebaliknya. Pada keseimbangan emosi yang ideal, timbangan harus condong ke arah emosi yang menyenangkan sehingga emosi itu mempunyai kekuatan melawan kerusakan psikologis yang ditimbulkan oleh dominasi yang tidak menyenangkan.

\section{Pengendalian emosi}

Pengendalian emosi berarti mengarahkan energi emosi ke 
saluran ekspresi yang bermanfaat dan dapat diterima secara sosial. Pengendalian emosi ini berpengaruh terhadap perilaku. Kemampuan menyesuaikan diri dan mengendalikan tindakan sesuai dengan usia, adalah proses pembelajaran yang mengarah pada sikap dan perilaku. Sikap dan perilaku ini perlu dibiasakan dalam pembelajaran dengan bimbingan yang intensif.

Menurut Daniel Goleman (1997), pengendalian emosi berkaitan dengan kecerdasan emosional, yaitu suatu kemampuan untuk merasakan, memahami, dan secara efektif merupakan daya dan kepekaan emosi sebagai sumber energi. Ciri-ciri kecerdasan emosional, antara lain adalah kemampuan mengenali diri sendiri, kemampuan menghadapi frustasi, kemampuan mengendalikan dorongan hati, kemampaun mengatur suasana hati, dan menjaga agar beban stres tidak melumpuhkan kemampuan berpikir.

Pengendalian emosi merupakan hal yang sangat penting bagi anak, sehingga mereka bisa menjadi pribadi yang bermoral. Dalam kaitan ini menurut Damon (dalam Shapiro, 1998), anakanak perlu memiliki keterampilan emosional dan sosial sebagai berikut: (1) mereka harus memahami perbedaan antara perilaku yang baik dan yang buruk, dan mengembangkan kebiasaan dalam perbuatan yang konsisten dengan sesuatu yang dianggap baik, (2) mereka harus mengembangkan kepedulian dan rasa tanggung jawab atas kesejahteraan dan hak-hak orang lain yang diungkapkan melalui sikap peduli, dermawan, ramah, dan pemaaf, dan (3) mereka harus merasakan reaksi emosi negatif, seperti malu, bersalah, marah, takut, dan rendah hati jika melanggar aturan moral.

Cara umum untuk menyalurkan emosi yang terpendam, menurut Hurlock (1995) adalah : (1) kemurungan, yaitu keadaan emosi yang diperpanjang, karena adanya energi emosi yang tertahan dan emosi itu dibiarkan tetap menyala; (2) reaksi pengganti, yaitu melepaskan energi emosional dengan mengganti reaksi emosional, yang biasanya dilakukan dengan reaksi yang lebih 
dapat diterima secara sosial (misalnya reaksi memukul diganti dengan reaksi caci maki); (3) pemindahan (displacement), yaitu reaksi emosional ditujukan kepada manusia, binatang, atau objek yang tidak ada hubungannya dengan rangsangan. Misalnya, anak yang marah bukannya memukul dan membentak orang yang telah menimbulkan kemarahannya, tetapi menyerang korban yang tidak bersalah sebagai kambing hitam; (4) regresi, yaitu salah satu cara umum untuk mengekspresikan emosi yang terhalang pada masa kanak-kanak, yaitu dengan kembali ke bentuk perilaku sebelumnya, bahkan perilaku yang infantil.

Menurut Sigmund Freud, belajar mengendalikan emosi merupakan tanda perkembangan kepribadian, yang akan menentukan apakah orang tersebut sudah beradab atau belum. Freud percaya bahwa kepribadian seorang anak yang sedang bertumbuh dibentuk oleh dua kekuatan besar, yaitu untuk mencari kesenangan dan berusaha menghindari rasa ketidaknyamanan.

Dalam dunia olah raga, emosi merupakan hal yang sangat penting untuk menentukan keberhasilan seorang atlit dalam suatu pertandingan. Dalam kaitan ini, emosi biasanya menimbulkan ketegangan dan kecemasan. Untuk melakukan pengendalian terhadap emosi tersebut diperlukan adanya teknik relaksasi.

\section{Kartasis emosi}

Katarsis emosi adalah pembersihan sistem energi yang terkurung, yang terjadi apabila ekspresi emosi dikendalikan. Ada katarsis fisik dan katarsis mental. Setiap aktivitas yang menggunakan seluruh energi yang dihasilkan oleh perubahan fisik yang menyertai emosi dan menimbulkan katarsis bagi energi ini dan memulihkan keseimbangan. Tiga bentuk katarsis yang umum dan menguntungkan adalah dengan cara menyibukkan diri, tertawa dan menangis. Untuk mencapai kartasis mental, anak-anak harus mengubah sikap terhadap situasi yang menimbulkan emosi mereka. Ini berarti mereka harus belajar mentolerir emosi dan menyadari sebab-sebab 
kemarahan, dukacita, ketakutan, dan kecemburuan mereka.

Untuk memberi bantuan kepada kartasis emosi antara lain dapat dilakukan sebagai berikut: (1) melakukan kegiatan menyibukkan diri sehari-hari, (2) mengadakan pemahaman bahwa kegiatan menyibukkan diri dapat membantu kesehatan fisik dan emosi, (3) mengembangkan rasa humor melalui tertawa, (4) memahami bahwa menangis tidak selalu merupakan perilaku negatif, tetapi dapat juga merupakan halhal yang positif, (5) mengadakan hubungan emosional yang akrab dengan salah satu anggota keluarga, (6) menceritakan kesulitan yang dialami dengan teman yang akrab, (7) kesediaan untuk memperbincangkan masalah dengan seseorang yang bersikap simpatik, dan (8) perlu adanya pengertian dari pihak lain terhadap sebab yang melatarbelakangi timbulnya emosi anak.

\section{Bahaya dalam perkembangan emosi}

Emosi memainkan peran penting dalam menentukan cara penyesuaian pribadi dan sosial pada anak-anak, remaja, dan orang dewasa. Segala sesuatu yang mengganggu perkembangan emosi yang baik akan menghambat penyesuaian yang dilakukan oleh anak. Di antara bahaya perkembangan emosi tersebut adalah sebagai berikut:
a. keterlantaran emosional;
b. terlalu banyak kasih sayang; dan
c. emosionalitas yang tinggi.

\section{KESIMPULAN}

Berdasarkan uraian di atas dapat diambil kesimpulan sebagai berikut:

1. Semua emosi memegang peranan penting dalam kehidupan anak, karena pengaruhnya terhadap penyesuaian pribadi dan sosial.

2. Sekalipun pola perkembangan emosi serupa pada semua anak tetapi ada variasi dalam bereaksi. Masing-masing anak akan 
bereaksi secara berlainan terhadap setiap emosi.

3. Perkembangan emosi dikendalikan oleh proses pematangan dan belajar.

4. Emosi anak berbeda dari emosi orang tua dalam hal intensitas, frekuensi pemunculan, ketetapan, kekuatan, sifat perorangan, dan dalam kesanggupannya untuk ditangkap melalui gejala perilaku.

5. Dua macam emosi yang paling umum pada masa kanak-kanak adalah kemarahan dan ketakutan.

6. Jika katarsis emosi digunakan secara efektif untuk mengatasi energi emosional yang terkurung maka anak akan memperoleh pemahaman tentang situasi yang telah menimbulkan emosi mereka. Katarsis emosi membersihkan tubuh dari energi yang tidak tersalur sehingga mencegah terjadinya ledakan emosi yang dapat menimbulkan penolakan sosial.

\section{DAFTAR PUSTAKA}

Feldmen, R. S. (1997). Understanding Psychology. Third edition. USA: McGraw Hill

Goleman, D (1998). Kecerdasan Emosional. Terjemahan oleh T Hermaya. Jakarta : PT Gramedia Pustaka Utama

Hurlock, Elizabeth B (1995). Perkembangan Anak. Terjemahan Meitasari

Tjandrasa dan Muslichah Zarkasih. Jakarta : Penerbit Erlangga

Semiawan, C. (1997) Perspektif Pendidikan Anak Berbakat. Jakarta :

Grasindo

Shapiro, Lawrence E (1998) Emotional Intelligence. Terjemahan Alex

Tri Kantjono Jakarta : PT Gramedia

Gunarsa, Singgih (1989). Psikologi Olah Raga. Jakarta : PT BPK Gunung Mulia

Winkel, WS (1983) Psikologi Pendidikan dan Evaluasi Belajar. Jakarta

: Gramedia 